\title{
Appraisal and composition of some traditional complementary foods for infant nutrition in Sierra Leone
}

\author{
Nyahabeh Mariama Anthony*1, 2, 3, Wasiu Akinloye Afolabi², Martha Shirley Epiphaneia Williams 1, 2, 3, \\ Bussie Mayiza-Dixon ${ }^{3}$, Oguntona Emmanuel Babatunde ${ }^{2}$
}

${ }^{1}$ Sierra Leone Agricultural Research Institute (SLARI), PMB 1313, Tower Hill Freetown, Sierra Leone

${ }^{2}$ Federal University of Agriculture, College of Food Science and Human Ecology, Department of Nutrition and Dietetics, PMB 2240, Abeokuta Ogun State, Nigeria

${ }^{3 *}$ International Institute of Tropical Agriculture (IITA), Food and Nutrition Unit, Ibadan, Nigeria

How to cite this paper: Anthony, N.M., Afolabi, W.A.. Williams, M.S.E., Mayiza-Dixon, B., Babatunde, O.E. (2020) Appraisal and composition of some traditional complementary foods for infant nutrition in Sierra Leone. International Journal of the Science of Food and Agriculture, 4(1), 73-79

DOI: $10.26855 /$ ijfsa.2020.03.011

Received: Demcember 25, 2019

Accepted: January 23, 2020

Published: March 9, 2020

*Corresponding author: Nyahabeh Mariama Anthony, International Institute of Tropical Agriculture (IITA), Food and Nutrition Unit, Ibadan, Nigeria.

Email: nyahabehanthony@yahoo.co.uk

\begin{abstract}
Malnutrition among infants in Sierra Leone still ranks one of the highest globally. Potency of some locally-formulated complementary food at resolving the problem had been proven. The experiment aimed at evaluating nutrient contents in traditional complementary foods consumed by infants in Eastern and Northern regions of Sierra Leone was carried out between 2016 and 2018. Ten common recipes identified through semi-structured questionnaire were standardized and analyzed using standard laboratory methods. Data were analyzed using SAS statistical package while means were separated using the new Duncan's Multiple Range Test. Results showed that Bennie-mix, pamahun, as well as pap prepared from rice, millet and rice-one pot are richer in protein content $(9.92 \%-16.87 \%)$ and essential micronutrients (Iron ranged from $0.45 \mathrm{mg}-3.58 \mathrm{mg}$ and zinc ranged from $1.24 \mathrm{mg}-$ $4.38 \mathrm{mg})$. phytate $(0.61 \mathrm{mg}-3.76 \mathrm{mg})$ and trypsin inhibitors $(0.26 \mathrm{mg}-5.79 \mathrm{mg})$ which were low in all the selected samples as recommended by WHO. It can be concluded that four out of the ten standardized traditional complementary foods are rich in macronutrient but required enhancement of the micronutrients
\end{abstract}

\section{Keywords}

Malnutrition, Complementary Food, Nutrients, Anti-Nutritional Factors And Prolonged Cooking

\section{Introduction}

Sierra Leone has 7,092,133 people with yearly change of two percent (2\%) and net change of one hundred and sixty one thousand and twenty two $(161,022)$ at density of one hundred and five persons per square kilometer $(105 / \mathrm{km} 2)$. Insufficient nutrition has over the years been a threat to the ever-increasing population [1]. The prevalence of stunting among infants (Children less than five) was forty four percent (44\%), twenty two percent $(22 \%)$ are severely stunted, and another twenty two percent (22\%) are underweight while approximately eight percent $(8 \%)$ of children within the same age group are wasted [2]. The Northern region having five district namely; Kambia, Bombali, Koinadugu Tonkolili, Port-kolo had the higest rate of infants malnutrition (40.5\%) and Eastern region having three district namely; Kailahun, Kenema and Kono had the second highest rate of infants malnutrition (36.6) [3]. Population of the malnourished infants 
is increasing across these regions and affected children often find it difficult to fulfill their socio-economic potentials. Inadequate nutrition has been a major hindrance to the mental, physical and cognitive performance of infants, and this had consequence on the gross economy of the country [4].

The concept of complementary feeding is to utilize hygienically formulated semi-solid food to feed infants simultaneously with breast milk, without necessarily replacing it Abeshu et al., [5] from the age of six (6) months. In Sierra Leone Complementary feeding starts between the ages of four and six months when mother's thinks breast milk can longer suffice their nutritional needs. Therefore other foods and liquids are needed, along with breast milk [6]. Any non-breast milk foods or nutritive liquids that are given to young children during this period are defined as complementary foods [7] suffice

Traditional ingredients, despite having some essential nutrients as the synthetics, are also expected to compare favorably with breast-milk and synthetics in terms of some properties and digestibility. Scientifically, it has been proven that breast milk contains all the required nutrients and antibodies for infant growth and development at their early life stage [8]. Most of the common ingredients used for preparing complementary food in West Africa, especially Sierra Leone are deficient in micro-nutrients [9]. Infant formulas are often beyond the reach of most households, who often depend on inadequately processed traditional foods consisting mainly rice, maize, cassava, sorghum and millet. The choice of the locally-available ingredients is favored by its availability, comparatively-cheaper price, ease of processing, popularity among African communities and general preference [10]. Continuous utilization of indigenous methods for preparation and inadequate knowledge about inherent nutritional properties of food ingredients among consumers in Sierra Leone is currently a challenge to quality assurance; therefore the need to evaluate some of the materials through standard laboratory procedures informed this study.

\section{Materials and methods}

\subsection{Sample preparation}

Ten traditional complementary food recipes collected from nursing mothers and caregivers from the Eastern and Northern region of Sierra Leone were earlier standardized in accordance with procedures of [11,12) at Food and Nutrition Unit (FNU), Njala Agricultural Research Centre, Njala, Sierra Leone. Ten cooks were recruited randomly from the list of respondents, five from each of the two regions. The ingredients, quantity and methods of preparation of each complementary food were obtained from administered questionnaires. These were dispensed using local measuring equipment such as cups, spoons, pints and tins. The five most common foods were selected from each region, making a total of ten dishes and the mean was calculated following the procedures described by Kayode et al., [13]

\subsection{Chemical analyses}

Moisture, fat, protein, fibre and ash content were determined in line with the procedures of the Association of Official Analytical Chemists [14] at the International Institute of Tropical Agriculture (IITA), Food and Nutrition unit Ibadan, Nigeria.

The carbohydrate content was determined by difference, subtracting the sum of moisture, ash, protein, fat, crude fibre percentage from a hundred, while energy was calculated in calorific value using Atwater factors of 4, 94 for protein, fat and carbohydrate respectively

\subsection{Functional property determination}

Functional properties such as water absorption capacity, water binding capacity, Dispersibility, bulk density, swelling power and solubility and anti-nutritional components (tannin, phytate acid and trypsin inhibitor) were determined following the procedures of [14]

Mineral elements such as: phosphorus $(\mathrm{P})$, calcium $(\mathrm{Ca})$, sodium $(\mathrm{Na})$ ) and potassium $(\mathrm{K})$, were determined by Atomic Absorption Spectrophotometry (AAS), while colorimetric method (i.e., Vanado-molybdate and 1, 10 phenanthroline) were used respectively to determine zinc ( $\mathrm{Zn})$ and iron $(\mathrm{Fe})$ content [15]. All analyses were carried out in three replications, while the average values were obtained as shown on tables 1,2,3 and 4 respectively.

\section{Statistical Analyses}

Significances among mean values were determined by analyses of variance (ANOVA), while means were thereafter separated with the New Duncan's Multiple Range Test (NDMRT) at five percent 5\% probability using the Statistical 
analysis system (SAS) version 20.1.

\section{Results}

\subsection{Proximate composition of the standardized traditional complementary foods}

The proximate composition of selected standardized traditional complementary foods is presented in Table 1 . The moisture content ranged from $2.91 \%$ in sweet potato ebbeh to $8.47 \%$ in maize pap. The fat content ranged from $0.17 \%$ in maize pap to $20.03 \%$ rice one pot, while the protein content recorded $2.03 \%$ in plantain pap to $16.87 \%$ in bennie mix

Generally, the result shows that fibre content was within $3.09 \%$ in pemahun to $13.57 \%$ in rice one pot, while ash content registered $2.06 \%$ in bennie mix to $7.16 \%$ in Plantain pap. The total carbohydrate content of the standardized complementary foods also ranged from $50.65 \%$ in rice one pot to $77.69 \%$ in plantain pap, while the energy value ranged from $308.96 \%$ in cassava flour pap to $427.29 \%$ (pemahun).

\subsection{Functional properties of the standardized traditional complementary foods}

Functional properties (Table 2) differed significantly among the traditional complementary foods collected. The Dispersibility of millet pap and rice one pot was significantly higher (85.0 and 84.7) than the other complementary foods, while bennie mix, sweet potato ebbeh, plantain pap and rice pap recorded similar values. Fufu pap registered the lowest dispersibility. Water absorption capacity was significantly $(\mathrm{p}<0.05)$ higher for pemahun than the other complementary foods, followed by sweet potato ebbeh, cassava flour pap and plantain pap, and significantly lower at $(\mathrm{P}<0.05)$ in fufu pap, millet pap and rice pap.

Table 1 Proximate composition of the standardized traditional complementary foods on semi dry weight basis (\%)

\begin{tabular}{|c|c|c|c|c|c|c|c|c|c|c|}
\hline Food Sample & Moisture & Fat & Protein & Fibre & Ash & Total CHO & Energykj & Amylose & Starch & Sugar \\
\hline Bennie-Mix & $5.98^{c}$ & $4.88^{\mathrm{e}}$ & $16.87^{\mathrm{a}}$ & $6.81^{\mathrm{f}}$ & $2.06^{\mathrm{h}}$ & $63.41^{\mathrm{g}}$ & $365.04^{\mathrm{e}}$ & $9.98^{\mathrm{g}}$ & $77.40^{\mathrm{c}}$ & $9.58^{\mathrm{c}}$ \\
\hline S. potato ebbeh & $2.91^{\mathrm{f}}$ & $0.41^{\mathrm{f}}$ & $8.26^{\mathrm{d}}$ & $8.09^{\mathrm{c}}$ & $4.05^{\mathrm{b}}$ & $76.28^{b}$ & $341.88^{f}$ & $11.49^{\mathrm{e}}$ & $16.98^{\mathrm{j}}$ & $1.08^{\mathrm{i}}$ \\
\hline C. Flour Pap & $6.83^{\mathrm{b}} \mathrm{b}$ & $0.67^{f}$ & $3.84^{\mathrm{f}}$ & $12.88^{\mathrm{b}}$ & $3.89^{c}$ & $71.90^{\mathrm{e}}$ & $308.96^{\mathrm{j}}$ & $10.93^{\mathrm{f}}$ & $59.97^{\mathrm{e}}$ & $4.30^{\mathrm{p}}$ \\
\hline Fufu Pap & $8.14^{\mathrm{a}}$ & $15.42^{\mathrm{c}}$ & $0.16^{\mathrm{h}}$ & $7.52^{\mathrm{d}}$ & $4.05^{b}$ & $64.71^{\mathrm{f}}$ & $398.22^{\mathrm{c}}$ & $12.05^{\mathrm{c}}$ & $28.64^{\mathrm{h}}$ & $11.58^{\mathrm{a}}$ \\
\hline Millet pap & $5.96^{\mathrm{c}}$ & $0.64^{\mathrm{f}}$ & $8.32^{\mathrm{d}}$ & $7.21^{\mathrm{e}}$ & $2.85^{\mathrm{g}}$ & $75.03^{\mathrm{c}}$ & $339.12^{\mathrm{g}}$ & $11.00^{\mathrm{f}}$ & $96.37^{\mathrm{a}}$ & $7.72^{\mathrm{e}}$ \\
\hline Maize Pap & $8.47^{\mathrm{a}}$ & $0.17^{\mathrm{g}}$ & $6.87^{\mathrm{e}}$ & $7.21^{\mathrm{e}}$ & $3.53^{\mathrm{d}}$ & $73.76^{\mathrm{d}}$ & $324.03^{\mathrm{h}}$ & $14.54^{\mathrm{b}}$ & $80.85^{\mathrm{b}}$ & $11.29^{b}$ \\
\hline Pemahun & $8.41^{\mathrm{a}}$ & $17.26^{\mathrm{b}}$ & $9.92^{\mathrm{c}}$ & $3.09^{\mathrm{h}}$ & $3.26^{\mathrm{e}}$ & $58.07^{\mathrm{h}}$ & $427.29^{a}$ & $9.14^{\mathrm{i}}$ & $48.33^{\mathrm{f}}$ & $2.12^{\mathrm{f}}$ \\
\hline Plantain pap & $6.13^{\mathrm{c}}$ & $0.42^{\mathrm{f}}$ & $2.00^{\mathrm{g}}$ & $6.61^{\mathrm{g}}$ & $7.16^{\mathrm{a}}$ & $77.69^{\mathrm{a}}$ & $322.52^{\mathrm{i}}$ & $14.71^{\mathrm{a}}$ & $19.82^{\mathrm{i}}$ & $1.21^{\mathrm{i}}$ \\
\hline Rice One Pot & $5.49^{\mathrm{e}}$ & $20.03^{\mathrm{a}}$ & $8.19^{d}$ & $13.57^{\mathrm{a}}$ & $2.08^{\mathrm{h}}$ & $50.65^{i}$ & $415.63^{b}$ & $9.63^{\mathrm{h}}$ & $33.60^{\mathrm{g}}$ & $1.03^{\mathrm{j}}$ \\
\hline Rice pap & $5.05^{\mathrm{e}}$ & $8.83^{\mathrm{d}}$ & $12.36^{\mathrm{b}}$ & $6.62^{\mathrm{g}}$ & $3.06^{\mathrm{f}}$ & $64.09^{\mathrm{g}}$ & $385.27^{d}$ & $11.63^{\mathrm{d}}$ & $76.17^{\mathrm{d}}$ & $9.1^{\mathrm{d}}$ \\
\hline
\end{tabular}

Note: Means with same letters are not significantly different from one another at $(\mathrm{P}<0.05)$

Legend CHO-Carbohydrate S. potato- Sweet potato C. Flour- Cassava flour

Table 2 Functional properties of the standardized traditional complementary foods on semi dry weight basis

\begin{tabular}{|c|c|c|c|c|c|c|}
\hline Food Sample & WAC (ml/100g) & WBC (ml/100g) & D (\%) & $\mathrm{BD}(\mathrm{g} / \mathrm{mg})$ & S P (\%) & Solubility (\%) \\
\hline Bennie Mix & $20.38^{\mathrm{d}}$ & $42.13^{\mathrm{f}}$ & $81.00^{\mathrm{b}}$ & $0.31 \mathrm{a}$ & $23.76^{\mathrm{c}}$ & $1171.44^{\mathrm{a}}$ \\
\hline Sweet potato ebbeh & $30.72^{b}$ & $73.16^{\mathrm{a}}$ & $79.50^{\mathrm{b}}$ & $0.31 \mathrm{a}$ & $24.89^{\mathrm{c}}$ & $1129.1^{\mathrm{a}}$ \\
\hline Cassava Flour Pap & $30.33^{\mathrm{b}}$ & $77.40^{\mathrm{a}}$ & $79.70^{\mathrm{b}}$ & $0.31 \mathrm{a}$ & $32.10^{\mathrm{b}}$ & $1157.11^{\mathrm{a}}$ \\
\hline Fufu Pap & $20.52^{\mathrm{d}}$ & $51.51^{\mathrm{d}}$ & $70.00^{c}$ & $0.31 \mathrm{a}$ & $21.04^{\mathrm{c}}$ & $1127.69^{\mathrm{a}}$ \\
\hline Millet Pap & $20.47^{\mathrm{d}}$ & $54.03^{d}$ & $84.70^{\mathrm{a}}$ & $0.32 \mathrm{a}$ & $18.99^{\mathrm{c}}$ & $1142.84^{\mathrm{a}}$ \\
\hline Maize Pap & $20.86^{\mathrm{c}}$ & $64.04^{b}$ & $79.80^{\mathrm{b}}$ & $0.31 \mathrm{a}$ & $51.33^{\mathrm{a}}$ & $1144.92^{\mathrm{a}}$ \\
\hline Pemahun & $30.83^{\mathrm{a}}$ & $65.49^{\mathrm{b}}$ & $80.20^{\mathrm{b}}$ & $0.31 \mathrm{a}$ & $20.27^{\mathrm{c}}$ & $1132.9^{\mathrm{a}}$ \\
\hline Plantain Pap & $30.22^{\mathrm{b}}$ & $77.62^{\mathrm{a}}$ & $79.70^{\mathrm{b}}$ & $0.30 \mathrm{a}$ & $32.92^{\mathrm{b}}$ & $1154.08^{\mathrm{a}}$ \\
\hline Rice-one-pot & $10.85^{\mathrm{e}}$ & $42.99^{f}$ & $85.00^{\mathrm{a}}$ & $0.31 \mathrm{a}$ & $22.72^{\mathrm{c}}$ & $1138.22^{\mathrm{a}}$ \\
\hline Rice pap & $20.45^{\mathrm{d}}$ & $55.78^{\mathrm{dc}}$ & $80.20^{\mathrm{b}}$ & $0.31 \mathrm{a}$ & $23.89^{\mathrm{c}}$ & $1158.25^{\mathrm{a}}$ \\
\hline
\end{tabular}

Note: Means with same letters are not significantly different from one another at $(\mathrm{P}<0.05)$

Legend WAC- Water absorption capacity WB- Water binding capacity D-Dispensability BD- Bulk density SP-Swelling power

Bulk density recorded no significant difference among all the standardized complementary foods. Water binding 
capacity was significantly the highest for sweet potato ebbeh, cassava flour pap and plantain pap, followed by maize pap and pemahun, while Bennie mix and rice one pot registered the lowest. The swelling power was significantly higher for maize pap (51.33\%) than the other complementary food. followed by cassava flour pap and plantain pap, while bennie mix, sweet potato ebbeh, fufu pap, millet pap, pemahun, rice one pot and rice pap recorded the least. The solubility registered no significant different among all the selected complementary foods (Table 2)

\subsection{Anti-nutritional content of the standardized traditional complementary foods}

Generally, distinct differences were observed among the standardized complementary foods for composition of anti-nutritional factors (Table 3). Pemahun recorded significantly at $(\mathrm{P}<0.05)$ highest tannin $(3.83 \%)$, followed by plantain pap (2.52), while sweet potato ebbeh recorded the lowest (1.27). Phytate content was significantly higher at ( $\mathrm{p}<$ 0.05 ) for sweet potato ebbeh (3.76), followed by bennie mix (3.31), while millet pap, pemahun and rice one pot (1.39, $1.29 \& 1.25)$ respectively showed similar value. Fufu pap, maize pap and plantain pap recorded the lowest phytate content.

Trypsin Inhibitor was significantly higher $(\mathrm{p}<0.05)$ for maize pap $(9.68)$ than the other selected complementary foods, while bennie mix, fufu pap, pemahun and rice pap followed with similar value. Cassava flour pap, sweet potato ebbeh, plantain pap and rice one pot recorded the least (Table 3).

\subsection{Mineral composition of the standardized traditional complementary foods}

The mineral composition in Table 4 revealed that maize pap had significantly the highest phosphorus content $(\mathrm{p}<0.05)$ $0.18 \mathrm{mg}$, followed by plantain pap $0.09 \mathrm{mg}$, while fufu pap $0.04 \mathrm{mg}$ recorded the least. Calcium content was higher in bennie mix $11.63 \mathrm{mg}$, while cassava flour and fufu pap had the lowest 0.16 and $0.17 \mathrm{mg}$ respectively.

Generally, potassium content ranged from $0.96 \mathrm{mg}$ in millet pap to $0.01 \mathrm{mg}$ in pemahun. Sodium was significantly higher ( $p<0.05$ ) in bennie mix $200.5 \mathrm{mg}$, followed by rice pap $138.5 \mathrm{mg}$, while fufu pap recorded the lowest. Iron, one of the most important mineral was significantly higher $(\mathrm{p}<0.05)$ in bennie mix $2.32 \mathrm{mg}$, followed by pemahun $2.29 \mathrm{~g}$, while fufu pap registered the least $0.15 \mathrm{mg}$. Zinc concentration ranged from $0.56 \mathrm{mg}$ in bennie mix to $0.12 \mathrm{mg}$ in fufu pap.

\section{Discussions}

The analysis of proximate composition determined the numerous components of the food material which is used as the basis for nutritional value and acceptability of a food product by consumers [16]. The lower moisture content observed in six of the standardized complementary food samples may be attributed to the thick consistency of the food. This predicts longer shelf-life on the said food samples and may slow microbial reactions (Fikiru et al., [17] and Amankwah., [18]). Fats forms an important part of food nutrient in promoting good health and establishing sensory qualities. It is good source of energy for infants and young children that provide fat-soluble vitamins and essential fatty acids WHO, [19]. Four of the standardized complementary foods (fufu pap, pemahun, rice one pot and rice pap) were within fat standard recommended for complementary foods for infants while the others were below the recommended rate WHO, [20].

Table 3 Antinutritional factors of the standardized traditional complementary foods on semi dry weight bas

\begin{tabular}{cccc}
\hline Food & Tannin $(\mathbf{m g} / \mathbf{1 0 0 g})$ & Phytate $(\mathbf{m g} / \mathbf{1 0 0 g})$ & Trypsin inhibitor $(\mathbf{m g} / \mathbf{1 0 0})$ \\
\hline Bennie Mix & $2.19^{\mathrm{c}}$ & $3.31^{\mathrm{b}}$ & $5.48^{\mathrm{b}}$ \\
Sweet potato ebbeh & $1.27^{\mathrm{g}}$ & $3.76^{\mathrm{a}}$ & $0.26^{\mathrm{d}}$ \\
Cassava flour pap & $2.02^{\mathrm{d}}$ & $0.98^{\mathrm{d}}$ & $0.17^{\mathrm{d}}$ \\
Fufu Pap & $1.93^{\mathrm{e}}$ & $0.61^{\mathrm{e}}$ & $4.92^{\mathrm{b}}$ \\
Millet pap & $1.93^{\mathrm{e}}$ & $1.39^{\mathrm{c}}$ & $2.83^{\mathrm{c}}$ \\
Maize Pap & $2.06^{\mathrm{d}}$ & $0.64^{\mathrm{e}}$ & $9.68^{\mathrm{a}}$ \\
Pemahun & $3.83^{\mathrm{a}}$ & $1.29^{\mathrm{c}}$ & $4.36^{\mathrm{b}}$ \\
Plantain pap & $2.52^{\mathrm{b}}$ & $0.74^{\mathrm{e}}$ & $1.91^{\mathrm{d}}$ \\
Rice one pot & $1.86^{\mathrm{f}}$ & $1.25^{\mathrm{c}}$ & $0.44^{\mathrm{d}}$ \\
Rice pap & $1.94^{\mathrm{e}}$ & $0.68^{\mathrm{e}}$ & $5.79^{\mathrm{b}}$ \\
\hline
\end{tabular}

Note: Means with same letters are not significantly different from one another $(\mathrm{P}<0.05)$

Table 4 Mineral composition of selected traditional standardized complementary foods on semi dry weight basis 


\begin{tabular}{ccccccc}
\hline Food & Phosphorus & Calcium & Potassium & Sodium & Iron(mg/100g) & Zinc(Mg/100g) \\
\hline Bennie mix & $0.03^{\mathrm{g}}$ & $11.63^{\mathrm{a}}$ & $0.43^{\mathrm{d}}$ & $200.5^{\mathrm{a}}$ & $2.32^{\mathrm{a}}$ & $0.56^{\mathrm{a}}$ \\
Sweet potato ebbeh & $0.06^{\mathrm{e}}$ & $0.26^{\mathrm{f}}$ & $0.04^{\mathrm{i}}$ & $114.5^{\mathrm{f}}$ & $0.21^{\mathrm{g}}$ & $0.23^{\mathrm{d}}$ \\
Cassava Flour Pap & $0.07^{\mathrm{d}}$ & $0.16^{\mathrm{g}}$ & $0.83^{\mathrm{c}}$ & $127.5^{\mathrm{c}}$ & $0.13^{\mathrm{i}}$ & $0.14^{\mathrm{f}}$ \\
Fufu Pap & $0.04^{\mathrm{f}}$ & $0.17^{\mathrm{g}}$ & $0.07^{\mathrm{h}}$ & $105.5^{\mathrm{h}}$ & $0.15^{\mathrm{h}}$ & $0.12^{\mathrm{g}}$ \\
Millet pap & $0.08^{\mathrm{c}}$ & $0.32^{\mathrm{e}}$ & $0.96^{\mathrm{a}}$ & $120.5^{\mathrm{d}}$ & $0.67^{\mathrm{f}}$ & $0.24^{\mathrm{d}}$ \\
Maize Pap & $0.18^{\mathrm{a}}$ & $0.26^{\mathrm{f}}$ & $0.21^{\mathrm{f}}$ & $117.5^{\mathrm{e}}$ & $1.75^{\mathrm{d}}$ & $0.19^{\mathrm{e}}$ \\
Pemahun & $0.08^{\mathrm{c}}$ & $4.63^{\mathrm{c}}$ & $0.01^{\mathrm{j}}$ & $112.5^{\mathrm{g}}$ & $2.29^{\mathrm{b}}$ & $0.55^{\mathrm{a}}$ \\
Plantain pap & $0.09^{\mathrm{b}}$ & $0.25^{\mathrm{f}}$ & $0.86^{\mathrm{b}}$ & $118.5^{\mathrm{e}}$ & $0.21^{\mathrm{g}}$ & $0.15^{\mathrm{f}}$ \\
Rice one pot & $0.05^{\mathrm{e}}$ & $0.71^{\mathrm{d}}$ & $0.39^{\mathrm{e}}$ & $121.5^{\mathrm{d}}$ & $1.37^{\mathrm{e}}$ & $0.34^{\mathrm{b}}$ \\
Rice pap & $0.04^{\mathrm{f}}$ & $9.27^{\mathrm{b}}$ & $0.07^{\mathrm{g}}$ & $138.5^{\mathrm{b}}$ & $2.24^{\mathrm{c}}$ & $0.46^{\mathrm{b}}$ \\
\hline
\end{tabular}

Note: Means with same letters are not significantly different from one another $(\mathrm{P}<0.05)$

Protein is an important nutrient in food especially for infants and young children as its very important for growth and development providing essential amino acids [5] Six out of ten standardized complementary foods adequately meet the nutritional needs of infants and young children between the ages of six months to 24 months WHO, [21]. Addition of legumes and fish to the food improved the protein content of food samples. Seven of traditional standardized complementary adequately met the requirement for infants between six months and twelve months WHO, [20]. The results from this study were above those reported by Hussain et al., [22]. Fiber of high content in food has been described to be harmful, possibly affecting protein, mineral digestion and absorption in human. Calcium, Zinc and iron may become unavailable for human nutrition by some fiber related fractions such as non-starch polysaccharides and polyphenol that bind minerals [23].

Low ash content was observed in all the traditional standardized complementary food indicating that the foods are insufficient in minerals [24]. This could be attributed to the processing methods of the ingredients such as washing, roasting, pounding or milling and sieving. All the standardized complementary foods in this work were higher in carbohydrate content, making them suitable nutrient as recommended by WHO/ FAO, [24] and Hussain et al., [22]

Pemahun had highest energy content and the least energy content was observed in cassava flour pap corroborating Steve and Babatunde, [25] who formulated complementary food from wheat and lentil composite flour. However, two out of the ten standardized complementary foods that is pamahun and rice one pot meet recommended energy (400-425 $\mathrm{kcal} / 100 \mathrm{~g}$ ) content as suggested by WHO/ FAO, [26] in complementary foods.

Water absorption capacity (WAC) is the ability of a product to associate with water under a condition where water is limiting [10]. Thus, four of the standardized complementary foods bonded well in little amount of water. Water binding capacity (WBC) means water that is retained by the food sample after processing. The importance of WBC in complementary diets is that it determines absorption and binding capacity [27]. High water binding capacity noticed in most of the sample used for this experiment is an indication that the samples were capable of adequately enhancing adsorption. However, every sample dispersed properly during reconstitution. The results obtained for the bulk density were slightly higher than one reported by Yusufu et al.,[29] for complementary food. Thus, the lower bulk density foods samples confirm that the standardized formula could be suitable for infant complementary foods and were bulky and gave desirable consistency, making them easily fed to infants.

Presence of anti-nutritional factors in food ingredient limits the body's ability to utilize certain amino acids and loss of some essential nutrients in food. Prolonged cooking and proper processing has been identified as ways by which its presence can be minimized. Presence of high concentration of anti-nutritional factor especially "trypsin inhibitor" in paps prepared from maize, rice, fufu as well as bennie mix and pamahun suggests that the products requires proper technique for preparation Mikić et al., [29]. The recommended iron density of complementary food for infants 6 to 8 months of age is $7.7 \mathrm{mg} / 100 \mathrm{kcal}$ for diets of low iron bioavailability compared with $4.6 \mathrm{mg} / 100 \mathrm{kcalfor}$ infants 9 to $11 \mathrm{months}$ [30]. In this study, all the selected standardized traditional complementary foods were considered to have low iron content that could meet the requirement of the target group. On the other hand, the recommended density for zinc in complementary food for infant 6 to 8 months of age is $1.6 \mathrm{mg} / 100 \mathrm{kcal}$. The result presented revealed that only bennie mix and pemahun 
$(3.04 \mathrm{mg} / 100 \mathrm{kcal})$ met the recommended density for zinc.

\section{Conclusion}

The main finding is that five traditional complementary foods products (Bennie-mix, pemahun, rice pap, millet pap and rich pap) have adequate macronutrient density, by WHO/FAO (2015) standard but lack micronutrient. Based on WHO recommendations, all the standardized and enriched complementary foods meet the energy requirement and will be adequate for infants $6-12$ months of age consuming such meals $2-3$ times daily.

\section{References}

[1] Sierra Leone Demographic and Health Survey 2016: Key Findings. Rockville, Maryland, USA: Statistics Sierra Leone and ICF International

[2] Sierra Leone Food and Nutrition security policy, 2016 implementation plan, Nutritional Situation of Sierra Leone Nutrition Survey, 2016. Report using SMART method. UNICEF

[3] United Nations Children's Fund (2012). Infant and Young Child Feeding Programming Guide. Nutrition Section, Programmes, UNICEF New York

[4] Multiple Indicator Cluster Survey., 2012. Final Report, Sierra Leone', Unicef, (December).

[5] Abeshu, M. A., Lelisa, A. and Geleta, B. (2016). Complementary Feeding: Review of Recommendations, Feeding Practices, and Adequacy of Homemade Complementary Food Preparations in Developing Countries - Lessons from Ethiopia', Frontiers in Nutrition.

[6] Kanu., P.J., Kanu. J.B., and Zhou. H., (2007). Studies on Physicochemical Composition of Bennimix: A Traditional Weaning Food. American Journal of Food Technology, 2: 652-661

[7] Castilho, S. D., Filho, A. B., 2010. The history of infant nutrition. Jornal de Pediatria.86 (3): 179-188

[8] Goldsmith, Peter (2011). The Role of the Private Sector in Agricultural Development1 An Executive Interview with Joseph Zed Bahsoon. International Food and Agribusiness Management Review Volume 14, Issue 1.

[9] Kassa, T., Meshesha, B., Haji, Y., Ebrahim, J., 2016. Appropriate complementary feeding practices and associated factors among mothers of children age 6-23 months in Southern Ethiopia, 2015'. BMC Pediatrics, 16(1): 131

[10] Shiriki, D., Igyor, M. A. and Gernah, D. I., (2015). Nutritional Evaluation of Complementary Food Formulations from Maize, Soybean and Peanut Fortified with Moringa oleifera Leaf Powder', Food and Nutrition Sciences 6: 494-500

[11] Okhiria, A.A., (2010). Nutritional Evaluation and Standardization of indigenous-dishes in the South-West of Nigeria. Ph.D Thesis, Federal University of Agriculture, Abeokuta, Nigeria. Pp 67-76

[12] Oguntona, C.R.B., Afolabi, A.O and Sosanya, B., (2003). Standardization, proximate composition and sensory evaluation of some Nigerian dishes. Nigerian Food Journal 21: 29-35.

[13] Kayode, O. F., Okafor, J. N. C., Adeyoju, O. A., Etoamaihe, M. A. and Ozumba, A U., 2008. Nutrient Composition and Sensory Evaluation of Selected Nigerian Traditional Soups. Journal of Industrial Research and Technology .Vol 2 Issue 1, page 37-42

[14] Association of Official Analytical Chemists (2012). Official Methods of Analysis of the Association of Analytical Chemists International, Washington, D. C.: AOAC; 2005

[15] Fernandez, D.R, VanderJagt, D.J, Millson, M., Huang, Y.S., Chuang, L.T., Pastuszyn, A, Glew, R.H., 2003. Fatty acid, amino acid and trace mineral composition of Eleusine corocana (Pwana) seeds from Northern Nigeria. Plant Foods in Human Nutrition. 58:1-10

[16] Butt, M. S, and Batool, R., (2010). Nutritional and functional properties of some promising legumes protein isolates. Pakistan. Journal of Nutrition 9 (4): 373-379

[17] Fikiru, O., Bultosa, G., Forsido, S.F. and Temesgen. M., (2017). Nutritional quality and sensory acceptability of complementary food blended from maize (Zea mays), roasted pea (Pisum sativum), and malted barley (Hordium vulgare). Food Science and Nutrition, volume 5, Issue 2 (13)

[18] Amankwah E.A., Barimah J., Acheampong R., Addai L.O., Nnaji C.O., (2009). Effect of fermentation and malting on the viscos- ity of maize-soyabean weaning blends. Pakinstan Journal of Nutrition. Volume 8, p.1671-1675. (14)

[19] World Health Organization (WHO), 2009. Infant and young child feeding: model chapter for textbooks for medical students and allied health professionals. Geneva: WHO Press. Available from: http://apps.who.int/iris/ bitstream/10665/ 44117/1/9 78924159749 4_en g.pdf

[20] WHO (World Health Organization), (2008). Guiding Principles for Complementary Feeding of the Breastfed Child. Geneva: Available from: http://www.who.int/nutrition/publications/guid ing_principles_compfeeding_breastfed

[21] World Health Organization and United Nations Children's Fund., (2003). Global Strategy for Infant and Young Child Feeding', World Health Organization, pp. 1-30. doi: ISBN 9241562218 
[22] Hussain, M. S., M. Anjam, B. Uddin, and M. Hanif. 2012. Preparation and evaluation of complementary diets from germinated wheat and lentil for Bangladeshi children. Pakistan. Journal of Science. 64:304-308

[23] Mosba TCE, Laswai HS, Tetens I (2000). Nutritional composition and micronutrient status of home made and commercial weaning foods consumed in Tanzania. Plant Foods Human Nutrition. 55(3): 185-205

[24] World Health Organization. WHO, 2015. Joint Food standards programme codex alimentarius commission', (March), pp. 1-5.

[25] Steve, I.O. and Babatunde, O.I., (2013). Chemical Compositions and Nutritional Properties of Popcorn-Based Complementary Foods Supplemented with Moringa oleifera Leaves Flour. Journal of Food Research 2:6

[26] WHO/ FAO. 2004. Human vitamin and mineral requirements. Report of a joint FAO/WHO consultation, Bangkok, Thailand. Rome: Food and Agriculture

[27] Daelmans, B., Ferguson, E., Lutter, C. K., Singh, N., Pachón, H.,et a., (2013).Designing appropriate complementary feeding recommendations: tools for programmatic action. Maternal and Child Nutrition, 9 (Suppl. 2), pp. 116-130

[28] Yusufu, P.A., Egbunu, F.A., Egwujeh, S.I.D., Opega, G.L. and Adikwu, M.O., (2013). evaluation of complementary food prepared from sorghum, african yam bean (Sphenostylis stenocarpa) and mango mesocarp flour blends. Pakistan Journal of Nutrition 12 (2): 205

[29] Mikić, A., Perić, V., Đorđević, V., Srebrić, M., Mihailović, V., (2009). Anti-nutritional factors in some grain legumes. Biotechnology in Animal Husbandry 25 (5-6), p 1181-1188.

[30] Pan American Health Organization, World Health Organization, 2003. Guiding Principles for complementary feeding of the breastfed child. Washington DC: 